\title{
Effects of high grade bentonite on performance, organ weights and serum biochemistry during aflatoxicosis in broilers
}

\author{
H. C. Indresh ${ }^{1}$, G. Devegowda ${ }^{2}$, S. Wilfred Ruban ${ }^{3}$ and M. C. Shivakumar ${ }^{4}$
}

1. Department of Livestock Production and Management, Veterinary College, Hassan - 573 201, Karnataka, India; 2. Former Professor \& Head, Division of Animal Science, Veterinary College, Hebbal, Bangalore - 24, Karnataka, India; 3. Department of Livestock Products Technology, Veterinary College, Hassan - 573 201, Karnataka, India;

4. Department of Livestock Production and Management, Veterinary College, Hassan - 573 201, Karnataka, India

Corresponding author: H. C. Indresh, email:drindreshpsc@gmail.com

Received: 17-09-2012, Accepted: 31-10-2012, Published online: 06-03-2013

How to cite this article: Indresh HC, Devegowda G, Ruban SW and Shivakumar MC (2013) Effects of high grade bentonite on performance, organ weights and serum biochemistry during aflatoxicosis in broilers, Vet. World 6(6):313-317, doi: 10.5455/vetworld.2013.313-317

\begin{abstract}
Aim: To evaluate the effect of different levels of High Bentonite on growth performance, organ weight and serum biochemistry in broiler fed on diets containing aflatoxin.

Materials and Methods: A total of 360 day-old commercial broiler chicks were divided at random into 8 dietary treatment groups of 42 chicks each having 3 replicates. Dietary levels of aflatoxin $(0.5 \mathrm{ppm})$ and High-grade bentonite $(0.5,0.75$ and $1.00 \%$ ) were tested in a completely randomized design manner, forming a total of 8 dietary treatments each with three replicates. Body weight and feed intake were recorded weekly. At $5 \mathrm{wk}$, six birds from each treatment were sacrificed and liver, kidney, gizzard, pancreas, spleen, bursa of Fabricius and thymus were extracted and weighed. The serum samples were analyzed for total proteins, uric acid, serum albumin, serum globulin and the activities of gamma glutamyl transferase (GGT), alanine amino transferase (ALT) and for antibody titers against Newcastle disease (ND) and infectious bursal disease (IBD) using ELISA technique.
\end{abstract}

Results: A significant $(P<0.05)$ decrease in body weight, feed consumption, relative weights of bursa, thymus, serum protein, anti body titers against NDV and IBDV, and increase in FCR, mortality, relative weight of liver, kidney, and the activity of Gamma Glutamyl Transferase (GGT) was observed. However, the relative weights of gizzard, pancreas, spleen, serum albumin, uric acid and the activity of Alanine Amino Transferase (ALT) were not influenced by inclusion of AF or HGB.

Conclusion: The addition of HGB restored the harmful effects of AF on body weight, feed consumption, FCR, mortality, relative weight of liver, kidney, serum protein, IBDV and NDV. Supplementation of high grade bentonite at 1.0 per cent level was found to be beneficial in ameliorating the adverse effects of aflatoxin (AF) in broiler chickens.

Keywords: aflatoxin, body weight, feed consumption, high grade bentonite, in-vivo

\section{I ntroduction}

Cereal grains and associated by-products constitute important sources of energy for poultry. However, there is increasing evidence that global supplies of cereal grains for animal feedstuffs are frequently contaminated with mycotoxins. It is estimated that as much as 25 percent of the world's cereals are contaminated with known mycotoxins [1].

Aflatoxins are secondary toxic metabolites, produced by certain strains of fungi, e.g. Aspergillus flavus and Aspergillus parasiticus species, of which aflatoxin B1 (AFB1), is the most toxic among all other aflatoxins i.e. AFB1, AFB2, AFG1 and AFG2. In poultry, aflatoxin ingestion leads to "Aflatoxicosis" syndrome that is characterized by retardation in growth, decreased feed consumption and feed conversion efficiency, immunosuppression and the increase of mortality [2]. Co-contamination of cereal grains with other mycotoxins produced by different fungal genera, including Fusarium and Aspergillus,

This article is an open access article licensed under the terms of the Creative Commons Attribution License (http://creativecommons. org/licenses/by/2.0) which permits unrestricted use, distribution and reproduction in any medium, provided the work is properly cited. has been reported to increase the toxicity symptoms in poultry [3].

Among Aflatoxins (AF), AFB1 is the most potent hepatotoxin having carcinogenic and severe performance depressive effects on poultry [4]. At present, one of the more encouraging approaches to make the feed harmless is the addition of non-nutritive and natural adsorbent materials to the contaminated feed in order to selectively bind the mycotoxin during the digestive process. The major advantages of these adsorbents include low cost, safety, and the ease of addition to animal feed.

Layered amino silicates, such as sodium bentonite, have been found effective in counteracting mycotoxins [5-9]. However, the ability of bentonite to bind mycotoxins depends on $\mathrm{pH}$, molecular arrangements, and its geographic region of origin [10]. Considering all these facts, the present study was undertaken to investigate the ability of high grade bentonite on aflatoxicosis in broilers.

\section{Material and Methods}

Experimental animals: A total of 336-day-old commercial broilers (Vencobb), were procured from a 
Table-1. Percent ingredient composition of basal diet

\begin{tabular}{|c|c|c|}
\hline Ingredients & $\begin{array}{l}\text { Broiler starter } \\
\text { (0-3 wks) }\end{array}$ & $\begin{array}{c}\text { Broiler finisher } \\
\text { (4-5 wks) }\end{array}$ \\
\hline Maize $(\mathrm{kg})$ & 63 & 69 \\
\hline Soybean meal extract $(\mathrm{kg})$ & 34 & 27.8 \\
\hline Mineral mixture ${ }^{1}(\mathrm{~kg})$ & 3.2 & 3.2 \\
\hline Salt (g) & 300 & 300 \\
\hline DL-methionine $(\mathrm{g})$ & 170 & 100 \\
\hline Vit. $A B_{2} D_{3} K^{2}(g)$ & 15 & 15 \\
\hline B complex ${ }^{3}(\mathrm{~g})$ & 20 & 20 \\
\hline Monocox (g) & 50 & 50 \\
\hline Oil $(\mathrm{kg})$ & - & 3.7 \\
\hline
\end{tabular}

1. Mineral premix Contained $29 \% \mathrm{Ca} ; 9 \% \mathrm{P} ; 0.44$ $\% \mathrm{Mn} ; 0.33 \% \mathrm{Zn} ; 150$ ppm I; 2000 ppm Fe; 250ppm Cu and 45 ppm Se.

2. $A B_{2} D_{3} K$ : Provided per kilogram of feed: Vitamin $A$ - 12375 IU, Vitamin B2 - 7.5 mg, Vitamin $D_{3}-1800$ IU, Vitamin $\mathrm{K}-15 \mathrm{mg}$.

3. B complex: Provided per kilogram of feed: Vitamin $B_{1}-0.8 \mathrm{mg}$, Vitamin $B_{6}-1.6 \mathrm{mg}$, Vitamin $\mathrm{B}_{12}-8 \mathrm{~g}, \mathrm{E}-8 \mathrm{mg}$, Niacin - $12 \mathrm{mg}$, calcium pantothenate $-8 \mathrm{mg}$

Monocox: A propriety product of Ranbaxy (India), containing maduramicin, an anticoccidial drug was mixed at the rate of $500 \mathrm{~g} /$ ton of feed.

Table-2. Effect of aflatoxin with or without High grade bentonite (HGB) on body weight $(\mathrm{g})$, cumulative feed consumption ( $g /$ bird $)$, feed conversion ratio of broiler chickens at $5^{\text {th }}$ wk of age (Mean $\left.\pm S E\right)$.

\begin{tabular}{|c|c|c|c|c|c|c|}
\hline AF (ppm) & & HGB (\%) & & Body weight (g) & $\begin{array}{l}\text { Cumulative feed } \\
\text { consumption (g/bird) }\end{array}$ & Feed conversion ratio \\
\hline- & - & - & - & $1313+0.88^{a}$ & $2513 \pm 6.07^{\mathrm{a}}$ & $1.91+0.003^{d}$ \\
\hline 0.5 & - & - & - & $1180 \pm 7.49^{c}$ & $2306+2.92^{b}$ & $2.09+0.005^{\mathrm{a}}$ \\
\hline- & 0.5 & - & - & $1314 \pm 11.11^{\mathrm{a}}$ & $2505 \pm 10.3^{\mathrm{a}}$ & $1.90 \pm 0.008^{d}$ \\
\hline- & - & 0.75 & - & $1326+4.91^{\mathrm{a}}$ & $2501 \pm 8.13^{a}$ & $1.88+0.006^{\mathrm{de}}$ \\
\hline- & - & - & 1.0 & $1339 \pm 10.07^{\mathrm{a}}$ & $2495 \pm 14.5^{\mathrm{a}}$ & $1.86 \pm 0.003^{\mathrm{e}}$ \\
\hline 0.5 & 0.5 & - & - & $1202 \pm 8.81^{c}$ & $2305+2.89^{b}$ & $2.05+0.006^{b}$ \\
\hline 0.5 & - & 0.75 & - & $1240 \pm 6.35^{b}$ & $2517 \pm 14.63^{\mathrm{a}}$ & $2.03 \pm 0.005^{b}$ \\
\hline 0.5 & - & - & 1.0 & $1274 \pm 0.73^{b}$ & $25367.77^{\mathrm{a}}$ & $1.99+0.005^{\mathrm{c}}$ \\
\hline
\end{tabular}

Means within each column bearing common superscript do not differ significantly $(P<0.05)$

local hatchery, divided at random into 24 replicates of 14 chicks each having equal number of males and females. Each three such groups were allotted to one of the 8 dietary treatments with due permission from the Animal Ethics committee of Veterinary College, Bangalore.

Experimental design and test diets: Dietary levels of AF $(0.5 \mathrm{ppm})$ and High-grade bentonite $(0.5,0.75$ and $1.00 \%$ ) were tested in a completely randomized design manner, forming a total of 8 dietary treatments each with three replicates. Basal diet was formulated and compounded to meet the nutrient requirements of commercial broilers during the starter (0-3 wks) and finisher (4-5 wks) phases (Table-1).

$\mathrm{AF}$ were produced using the pure culture of Aspergillus parasiticus MTCC 1894 (Microbial Type Culture Collection and Gene Bank, IMT, Chandigarh, India) grown on potato dextrose agar. Then $\mathrm{AF}$ produced on relevant Medias were extracted [11] and quantified by thin layer chromatography [12]. Individual ingredients were screened for mycotoxin content prior to compounding the feed. Compounded feed was analyzed for the presence of AF before including the rice and wheat culture materials, and then the diets were prepared by incorporating required quantities $(0.5 \mathrm{ppm})$ of rice/wheat culture containing AF into the diet. To the basal diet High-grade bentonite at $0.5,0.75$ and 1.00 percent were added to prepare the different experimental diets. Compounded experimental diets were analyzed for mycotoxin content to counter check the required levels. Chicks were fed ad libitum. Feeding of test diets commenced at zero day of age and continued till the termination of experiment at five weeks of age.

Data collection: Body weight and feed intake were recorded weekly. At $5 \mathrm{wk}$, six birds from each treatment (3 males and 3 females) were humanely slaughtered as per religious (Halal) method of slaughter by severing the carotid arteries and jugular veins and liver, kidney, gizzard, pancreas, spleen, bursa of Fabricius and thymus were collected and weighed. The weights were adjusted to one $\mathrm{kg}$ live weight and the treatment means were calculated.

Blood was collected in non-heparinized tubes from six birds in each treatment $(3$ males and 3 females) by puncturing the brachial vein during 5 th week of age. Serum was collected after 8 to 10 hours as per the standard procedures [13] and was stored at $-200 \mathrm{C}$ for subsequent analysis. The individual serum samples were analyzed for total proteins, uric acid, serum albumin, serum globulin and the activities of gamma glutamyl transferase (GGT), alanine amino transferase (ALT) using automatic analyzer (Boehringer Mannheim Hitachi 704 automatic analyzer, Japan). The methodology and the set of reagents used in respect of each parameter were as per the recommendations of the manufacturer of the analyzer system. Data are presented as means of each treatment. The serum samples were assayed for antibody titers against Newcastle disease (ND) and infectious bursal disease (IBD) using ELISA technique at five weeks of age. Treatment-wise means of titers were calculated.

Statistical analysis: The results were subjected to oneway analysis of variance. Means were compared using Tukey method [14]. The level of significance was tested $(P<0.05)$.

\section{Results and Discussion}

Growth performance: Birds fed on aflatoxin 
Table-3. Effect of aflatoxin with or without High grade bentonite (HGB) on organ weights ( $\mathrm{g} / \mathrm{kg}$ live wt. ) and lymphoid organ weights of broiler chickens at $5^{\text {th }}$ wk of age (Mean $\pm S E$ ).

\begin{tabular}{|c|c|c|c|c|c|c|c|c|c|c|}
\hline \multicolumn{2}{|l|}{ AF (ppm) } & \multicolumn{2}{|c|}{ HGB (\%) } & \multirow{2}{*}{$\frac{\text { Liver }}{27.60 \pm 0.76^{\mathrm{c}}}$} & \multirow{2}{*}{$\frac{\text { Kidney }}{8.16 \pm 0.16^{b}}$} & \multirow{2}{*}{$\frac{\text { Gizzard }}{24.53 \pm 0.60}$} & \multirow{2}{*}{$\frac{\text { Pancreas }}{5.10+0.17}$} & \multirow{2}{*}{$\begin{array}{l}\text { Thymus } \\
4.36+0.21^{\mathrm{a}}\end{array}$} & \multirow{2}{*}{$\frac{\text { Bursa }}{1.69 \pm 0.02^{a}}$} & \multirow{2}{*}{$\begin{array}{l}\text { Spleen } \\
1.57+0.28\end{array}$} \\
\hline- & - & - & - & & & & & & & \\
\hline 0.5 & - & - & - & $33.00 \pm 0.57^{\mathrm{a}}$ & $9.66+0.16^{a}$ & $25.67 \pm 1.20$ & $4.66+0.33$ & $2.66 \pm 0.33^{b}$ & $1.16 \pm 0.16^{b}$ & $1.66+0.16$ \\
\hline- & 0.5 & - & - & $27.67 \pm 0.42^{c}$ & $8.33+0.16^{b}$ & $25.73+0.52$ & $4.16 \pm 0.03$ & $4.03 \pm 0.12^{\mathrm{ab}}$ & $1.69 \pm 0.03^{\mathrm{a}}$ & $1.51 \pm 0.16$ \\
\hline - & - & 0.75 & - & $28.63+0.23^{b c}$ & $8.16+0.16^{b}$ & $25.97+0.21$ & $4.66+0.26$ & $4.06 \pm 0.40^{\mathrm{ab}}$ & $1.68 \pm 0.04^{a}$ & $1.57 \pm 0.16$ \\
\hline- & - & - & 1.0 & $30.43 \pm 1.03^{\mathrm{abc}}$ & $8.33 \pm 0.16^{b}$ & $24.60+0.69$ & $4.80 \pm 0.30$ & $4.16 \pm 0.06^{a}$ & $1.82 \pm 0.04^{\mathrm{a}}$ & $1.59+0.16$ \\
\hline 0.5 & 0.5 & - & - & $31.33 \pm 0.33^{\mathrm{ab}}$ & $9.00 \pm 0.28^{\mathrm{ab}}$ & $26.00 \pm 1.15$ & $4.66 \pm 0.33$ & $2.66 \pm 0.33^{b}$ & $1.33 \pm 0.16^{\mathrm{ab}}$ & $1.67 \pm 0.16$ \\
\hline 0.5 & - & 0.75 & - & $30.00 \pm 0.57^{b c}$ & $8.83 \pm 0.16^{b}$ & $25.33+0.33$ & $4.33 \pm 0.33$ & $3.33 \pm 0.33^{\mathrm{ab}}$ & $1.33 \pm 0.16^{\mathrm{ab}}$ & $1.65+0.16$ \\
\hline 0.5 & - & - & 1.0 & $30.00 \pm 0.57^{\mathrm{bc}}$ & $8.33 \pm 0.16^{b}$ & $24.67 \pm 0.88$ & $4.33 \pm 0.33$ & $3.66 \pm 0.33^{\mathrm{ab}}$ & $1.50 \pm 0.00^{\mathrm{ab}}$ & $1.66 \pm 0.16$ \\
\hline
\end{tabular}

Means within each column bearing common superscript do not differ significantly $(P<0.05)$

Table-4. Effect of aflatoxin with or without High grade bentonite (HGB) on antibody titers against ND and IBD in broilers at $5^{\text {th }}$ wk of age (Mean $\underline{+S E})$

\begin{tabular}{llclll}
\hline AF $(\mathbf{p p m})$ & HGB (\%) & & ND titer & IBD titer \\
\hline- & - & - & - & $4298 \pm 17.05^{\mathrm{ab}}$ & $4281 \pm 8.083^{\mathrm{a}}$ \\
0.5 & - & - & - & $3204 \pm 106.3^{\mathrm{e}}$ & $3149 \pm 69.72^{\mathrm{d}}$ \\
- & 0.5 & - & - & $4018 \pm 119.2^{\mathrm{bc}}$ & $4252 \pm 21.79^{\mathrm{a}}$ \\
- & - & - & - & $4305 \pm 93.19^{\mathrm{ab}}$ & $4329 \pm 25.48^{\mathrm{a}}$ \\
- & - & - & - & $4418 \pm 56.72^{\mathrm{a}}$ & $4378 \pm 26.74^{\mathrm{a}}$ \\
0.5 & 0.5 & - & - & $3582 \pm 30.19^{\mathrm{d}}$ & $3352 \pm 73.59^{\mathrm{cd}}$ \\
0.5 & - & - & 1.0 & $3797 \pm 10.73^{\mathrm{cd}}$ & $3694 \pm 73.64^{\mathrm{bc}}$ \\
0.5 & - & - & $4225 \pm 78.83^{\mathrm{ab}}$ & $4046 \pm 182.3^{\mathrm{ab}}$ \\
\hline
\end{tabular}

Means within each column bearing common superscript do not differ significantly $(P<0.05)$

contaminated feed $(0.5 \mathrm{ppm})$ showed a significant $(P<0.05)$ decrease in body weight, feed intake and increased FCR. The result of present investigation was in accordance to the observations of [15-19].

The addition of 0.75 and 1.0 per cent HGB significantly restored the body weight, feed intake and FCR (Table-2). The present results relating to the use of Bentonite in AF containing diets is in agreement with the findings of [20-22] who opined that improvement in body weight upon bentonite inclusion may be due to their montmorillonites content that bind irreversibly with toxin in the gut and thereby preventing absorption of the toxin across the intestinal wall, providing a prophylactic action.

High mortality rate of 14.20 per cent was observed in group fed with diet containing $0.5 \mathrm{ppm}$ AF. Similar mortality rate in broilers due to AF toxin were reported by several workers [17, 23-26] Mortality rate was reduced considerably in control as well as in the groups supplemented with $0.5,0.75$ and 1.0 per cent HGB. who reported. The results were in accordance with the findings of [20], who reported a significant reduction in mortality of broilers upon addition of 0.5 per cent bentonite to $0.5 \mathrm{ppm}$ aflatoxin containing diets.

Organ weights: The relative weights of liver (19.56\%), and kidney $(18.38 \%)$ increased significantly $(\mathrm{P}<0.05)$ with addition of $0.5 \mathrm{ppm}$ AF (Table-3), whereas improvement was observed with dietary inclusion of 0.75 and 1.0 per cent HGB. The increase in liver and kidney weights were in accordance with the findings of [17-19, 27, 28]. The increase in liver weight could be attributed to increased lipid deposition in liver due to impaired fat metabolism [29]. The protective effects of bentonite against $\mathrm{AF}$ induced organ weight increase in broilers were in accordance with [20,21,30]. Compared with control, relative weights of gizzard and pancreas were not affected either in AF fed group, control and HGB supplemented groups. The relative thymus $(38.99 \%)$ and bursal weights $(31.36 \%)$ were significantly $(P<0.05)$ lower at $0.5 \mathrm{ppm}$ inclusion of AF group (Table-3) compared to control diet. A Similar reduction in relative weights of thymus and bursa with $\mathrm{AF}$ were reported by $[4,17,27,28]$.

Relative weights of thymus and bursal were not altered by supplementation of varying levels of HGB compared to control diets. Compared with control, relative weight of spleen was not affected either in AF fed group or HGB supplemented groups. The protective effects of HGB may be due to sequestration of AF in the gut which reduces bioavailability of the AF toxin.

Serum Biochemistry: The Serum antibody titres against $\mathrm{ND}$ and IBD vaccination were significantly $(P<0.05)$ depressed by aflatoxin which were restored with the inclusion of 1.0 per cent HGB (Table-4). These findings agree with the previous reports of decreased antibody titres against ND and IBD in AF fed broilers $[31,32,33,34]$. The decreased antibody titers could be due to inhibition of DNA and protein synthesis by aflatoxin through impairment of amino acid transport and m-RNA transcription resulting in lowered level of antibody production [35].

The results clearly demonstrated the protective effects of bentonite at 1.0 per cent inclusion to aflatoxin diet in chickens. The findings of present study were comparable to the reports of [36] who reported an improved antibody titres in chickens fed on aflatoxin. 
Table-5. Effect of aflatoxin with or without High grade bentonite (Ashafeed) on levels of serum biochemical parameters and serum enzyme activities of broilers at $5^{\text {th }}$ wk of age (Mean \pm SE).

\begin{tabular}{|c|c|c|c|c|c|c|c|c|}
\hline AF (ppm) & & HGB (\%) & & Serum protein (g \%) & Serum Albumin (g \%) & Uric acid $(\mu \mathrm{g} / \mathrm{dl})$ & GGT (IU/L) & ALT (IU/L) \\
\hline- & - & - & - & $2.7 \pm 10.17^{\mathrm{a}}$ & $1.28 \pm 0.17$ & $647.9 \pm 7.54$ & $9.53 \pm 1.15^{d}$ & $28.17 \pm 0.60$ \\
\hline 0.5 & - & - & - & $1.67 \pm 0.15^{b c}$ & $1.10+0.18$ & $600.4 \pm 6.73$ & $17.8 \pm 1.72^{\mathrm{ab}}$ & $25.83 \pm 1.36$ \\
\hline- & 0.5 & - & - & $2.43 \pm 0.23^{\mathrm{abc}}$ & $1.23 \pm 0.06$ & $610.6 \pm 0.69$ & $11.65 \pm 0.37^{\mathrm{bcd}}$ & $25.07 \pm 1.47$ \\
\hline- & - & 0.75 & - & $2.51 \pm 0.20^{\mathrm{ab}}$ & $1.26 \pm 0.07$ & $629.0+2.02$ & $11.65+0.14^{\mathrm{bcd}}$ & $28.6 \pm 1.62$ \\
\hline- & - & - & 1.0 & $2.72 \pm 0.15^{a}$ & $1.36 \pm 0.06$ & $653.6 \pm 3.01$ & $10.6 \pm 0.96^{\mathrm{cd}}$ & $29.67 \pm 2.34$ \\
\hline 0.5 & 0.5 & - & - & $1.66 \pm 0.11^{b c}$ & $1.14 \pm 0.17$ & $6143 \pm 4.09$ & $22.57 \pm 2.16^{a}$ & $27.73 \pm 0.34$ \\
\hline 0.5 & - & 0.75 & - & $1.61 \pm 0.15^{\mathrm{c}}$ & $1.19+0.17$ & $610.6 \pm 3.00$ & $17.47 \pm 2.25^{\mathrm{ab}}$ & $28.67 \pm 0.14$ \\
\hline 0.5 & - & - & 1.0 & $2.57 \pm 0.22^{a}$ & $1.27 \pm 0.37$ & $636.3 \pm 6.98$ & $13.7 \pm 1.01^{b c d}$ & $28.87 \pm 0.49$ \\
\hline
\end{tabular}

Means within each column bearing common superscript do not differ significantly $(P<0.05)$

The serum concentration of total protein $(38.37 \%)$ significantly $(P<0.05)$ decreased by addition of aflatoxin (Table-5), but was elevated to normal level with the inclusion of 1.0 per cent HGB. Serum concentration of uric acid and albumin were not affected either in AF fed group or HGB supplemented groups (Table 5). Reduced levels of serum total protein, serum uric acid and serum albumin in $\mathrm{AF}$ fed diets were reported earlier [23, 27, 29].

The activity of serum GGT significantly $(P<0.05)$ increased in AF fed group (Table-5). The addition of graded levels of HGB to AF containing diet did not show significant reduction in the activity of serum GGT. Activity of serum ALT was not affected either in AF fed group or control and HGB supplemented groups (Table-5). The increased serum enzyme activity as observed during aflatoxicosis is interpreted as the sequalae of hepatocyte degeneration and subsequent leakage of enzymes into the circulation $[29,37]$.

\section{Conclusions}

Growth performance, organ weights and serum profile of broilers were significantly $(P<0.05)$ altered by the aflatoxin, indicating their adverse effects on the general health of broilers. Supplementation of high grade bentonite at 1.0 per cent level was found beneficial in ameliorating the adverse effects of AF in broiler chickens.

\section{Authors' contribution}

HCI carried out the experiment. GD designed the experiment, guided during the experiment. SWR and MCS helped in analysis of data, drafted and revised the manuscript. All authors read and approved the final manuscript.

\section{Acknowledgements}

The authors are thankful to The Dean, Veterinary College, KVAFS University, Bangalore for providing the basic facilities for the conduct of the research.

\section{Competing interests}

Authors declare that they have no competing interests.

\section{References}

1. Manafi, M., Narayana Swamy, H. D. and Pirany, N. (2009)
In vitro Binding Ability of Mycotoxin Binder in Commercial Broiler Feed. African J. Agri. Res. 4(2):141-143.

2. Mohamadi, H. and Alizadeh, M. (2010) A Study of the Occurrence of Aflatoxin M1 in Dairy Products Marketed in Urimia, Iran. J. Agri. Sci. Tech. 12: 579-583.

3. Hagler, W. M., Tyczkowska, K. and Hamilton, P. B. (1984) Simultaneous Occurrence of Deoxynivalenol, Zearalenone and Aflatoxin in 1982 Scabby Wheat from Midwestern United States. Appl. Environ. Microbiol.47: 151-154.

4. Devegowda, G. (2002) Mycotoxins: Economic risks and their control. In: Handbook of Poultry Nutrition. Published by American Soybean Association, pp. 246-260.

5. Smith, J. E. and Ross, K. (1991) The Toxigenic Aspergilli. In: "Mycotoxins and Animal Foods", (Eds.): Smith, J. E. and Henderson, CRC Press, Boca Raton, PP. 101-118.

6. Santurio, J. M., Mallmannl, C. A., Rosa, A. P., Appel, G., Heer, A., Dageforde, S. and Bottcher, M. (1999) Effect of Sodium Bentonite on the Performance and Blood Variables of Broiler Chickens Intoxicated with Aflatoxin. Brit. Poultry Sci. 40: 115-119.

7. Hagler, W. M., Jr. Grimes, J. and Fairchild, L. (1992) Effects of Astra-Ben 20® on Broiler Chicks Exposed to AFB1 or T-2 Toxin. North Carolina State University. Poultry Abstract. 16: 123.

8. Rosa, C. A. R., Miazoo, R., Magnoli, C., Salvano, M., Chicchiera, S. M., Ferrero, S., Saenz, M., Carvalho, E. C. Q. and Dalcero, A. (2001) Evaluation of the Efficacy of Bentonite from the South Argentina to Ameliorate the Toxic Effects of Aflatoxin in Broilers. Brit. Poultry Sci. 32: 100108.

9. Eralsan, G., Essz, D., Akdogan, M., Sahindokuyucu, F. and Altrintas, L. (2005) The Effects of Aflatoxin and Sodium Bentonite and Alone on Some Blood Electrolyte Levels in Broiler Chickens. Turk Vet. Hayvanclk Dergisi. 29: 601-605.

10. Vieira, S.L. (2003) Nutritional implication of mould development in feed stuffs and alternatives to reduce the mycotoxin problem in poultry feeds. World's Poultry Science Journal, 59: 111-122.

11. Rukmini, C. and R.V. Bhat. (1978) Occurrence of T- 2 toxin in Fusarium infested sorghum from India. J. of Agri. Food Chemist. 26: 647-649.

12. AOAC. (1995) Official Methods of Analysis.16th Edn. Association of Official Analytical Chemists, Arlington, VA.

13. Calnek, B.W., Barnes, H.J., Beard, C.W., Reid, W.M. and yoder, Jr. H.W. (1992) Diseases of Poultry, $9^{\text {th }}$ Edn., Wolfe Publishing, Ltd., USA.

14. Snedecor, G.W. and W.G.Cochran. (1989) Statistical methods. Sixth ed. Iowa State University Press. Ames. Owa.

15. Swamy, H.V.L.N. and Devegowda, G. (1998) Ability of mycosorb to counteract aflatoxicosis in commercial broilers. Indian J. Poult. Sci. 33: 273-278.

16. Sapcota, D., Islam, R. and Bamah, K.K. (2005) Effect of dietary methomin as a counteracting agent in experimental aflatoxicosis of broilers. Ind. J. Poult. Sci. 40(2): 184-186.

17. Raju, M.V.L.N. and Devegowda, G. (2000) Influence of esterified glucomannan on performance and organic morphology, serum biochemistry and haematology in 
broilers exposed to individual and combined mycotoxicosis (aflatoxin, ochratoxin and T-2 toxin). Br. Poult. Sci. 41:640650.

18. Arvind, K.L., Patil, V.S. and Devegowda, G., Umakantha, B. and Ganpule, S.P. (2003) Efficacy of Esterified glucomannan to counteract Mycotoxicosis in naturally contaminated feed on performance, serum biochemical and hematological parameters in broilers. Poult. Sci. 82:571-576.

19. Girish, C.K. (2003) Efficacy of modified glucomannan and hydrated sodium calcium aluminosilicate to alleviate the individual and combined toxicity of aflatoxin and T-2 toxin in broiler chickens. M.V.Sc. Thesis, Univ.Agric. Sci., Bangalore.

20. Barmase, B.S., Devegowda, G. and Devurkar, U. (1990) Reversal of aflatoxicosis through dietary adsorbents in broiler chickens. Proc. $13^{\text {th }}$ Annual Conf. Symp. Indian Poultry Sci. Assoc., Bombay, pp. 20-22.

21. Chaturvedi, V.B. and Singh, K.S. (2004) Effect of Aflatoxin and hydrated sodium bentonite on nutrient utilization in chickens. Animal Nutrition and Feed Technology. 4(2): 187195.

22. Sellers, R.S., Harris, G.C. and Waldroup, P.W. (1980) The effects of various dietary clays and fillers on the performance broilers and laying hens. Poult. Sci. 59: 1901-1906.

23. Kubena, L.F., Harvey, R.B., Huff, W.E., Carier, D.E., Phillips, T.D. and Rottinghaus, G.E. (1990) Efficacy of hydrated sodium calcium aluminosilicate to reduce the toxicity of aflatoxin and T-2 toxin. Poult. Sci. 69: 1078-1086.

24. Rao, A.T., and Chakravarthy, B.S. (2000) Effect of levamisole on immune status in experimental aflatoxicosis in chickens. Ind. J. of Vety. Pathology. 24:1-2.

25. Behera, A., Mishra, S.C., Mishra, P.K., and Dehung, P.K. (2002) Comparative efficacy of livol and improved product (research name LCSL-L) in relation to body weight, feed conversion ratio and mortality in aflatoxin affected broiler chicks. Phytomedica. 3: 59-66.

26. Gupta, K., Amarjit singh. (2003) Experimental studies on aflatoxicosis, infectious bursal disease and their interaction in broiler chicks. Ind. J. Vety. Pathology. 27(1): 5-7.

27. Perozo, F and Rivera, S. (2003) Effect of Aflatoxin $B_{1}$ exposure and selenium supplementation on immune response in broilers. Indian Vet.J. 80(12): 1218-1221.

28. Miazzo, R., Pevalta, M.F., Magnoli, C., Salvano, M., Ferrero, S., Chiacchiera, S.M., Carralno, E.C.Q., Rosa, C.A.R. and Dalcero, A. (2005) Efficacy of sodium bentonite as a detoxifier of broiler fed contaminated with aflatoxin. Poult. Sci. 84(1):1-8.

29. Batina, P.N., Lopes, S.T.Dos. A, Santurio, J.m., Souza, C.de, and Mortine, D.B. (2005) The effects of the addition of sodium montomorillonite on the feeding diet on the biochemicalprofile of broiler chicken intoxicated by aflatoxin. Ciencia-Rural.35(4):826-831.

30. Eraslan, G., Akdogan, M., Yarsan, E., Essiz, D., Sahndokuyucu, F., Hsmogullar, S.E., and Altantas, L. (2004) Effects of Aflatoxin and sodium bentonite administered in feed alone or combined on lipid peroxidation in the liver and kidneys of broilers. Bulletin of the Veterinary Institute in Puawy. 48(3): 301-304.

31. Devegowda, G., Arvind, B.I.R., Rajendra, K., Morton, M.G., Baburathna, A. and Sundareshan, C. (1994) A biological approach to counteract aflatoxicosis in broiler chickens and ducklings by the use of Saccharomyces cerevisiae cultures added to feed. In: Biotechnology in the Feed Industry. Eds. T.P. Lyons and K.A. Jacques. Proc. Altech's $10^{\text {th }}$ Ann. Symp., Ky, USA, pp. 235-245.

32. Gupta,S., Jindal, N., Khokhar, R.S., Gupta, A.K., Ledoux, D.R. and Rottinghans, G.E. (2005) Effect of Ochratoxin A on broiler chicks challenged with Salmonella gallinarum. British Poultry Science. 46(4): 443-450.

33. Ibrahim, I.K., shareef, A.M., AI. Joubory, KMT. (2000) Ameliorative effects of sodium bentonite on phagocytosis and Newcastle disease antibody formation in broiler chickens during aflatoxicosis. Research in Vety. Science. 69:2, 119-122.

34. Kumar, M.R., Kumar, H.S.A., Kalakumar, B. and Reddy, K.S. (2002) Effect of Zeetress on Aflatoxin induced humoral immunosuppression in broiler chicks. Indian $J$ of Comparative Microbiology and Infectious Disease. 23(2): 203-204.

35. Thaxton, J.P., Timb, J.T. and Jaotpm, B. (1974) Immunosuppression in chicken by aflatoxin. Poult. Sci. 53: 721-725.

36. Daoud, A.Z. (2002) Amelioration of Na-bentonite of Aflatoxin depressive effect on the antibody protection after new castle disease vaccination in broilers. Iraqi J. of Vety. Science. 16(2):161-165.

37. Nataraj, T.H., Swamy, H.D.N., Vijayasarathi, S.K., Kumar, B.S. and Prakash, G.C. (2004) Pathomorphological study of liver and kidneys in aflatoxicosis and T-2 toxicosis in broiler chickens. Indian Journal of Anim. Science. 74(9): 944-945. 